\title{
Thermosonication for the Production of Sulforaphane Rich Broccoli Ingredients
}

\author{
Sajad Shokri ${ }^{1,2}{ }^{,}$Hema Jegasothy ${ }^{1}$, Mary Ann Augustin ${ }^{1}$ and Netsanet Shiferaw Terefe ${ }^{1, *(D)}$ \\ 1 CSIRO Agriculture and Food, 671 Sneydes Road, Werribee, VIC 3030, Australia; s.shokri@shirazu.ac.ir (S.S.); \\ Hemalatha.jegasothy@csiro.au (H.J.); maryann.augustin@csiro.au (M.A.A.) \\ 2 Department of Food Hygiene and Control, Shiraz University, Shiraz 71454, Iran \\ * Correspondence: netsanet.shiferawterefe@csiro.au
}

\section{check for} updates

Citation: Shokri, S.; Jegasothy, H.; Augustin, M.A.; Terefe, N.S.

Thermosonication for the Production of Sulforaphane Rich Broccoli Ingredients. Biomolecules 2021, 11, 321. https://doi.org/10.3390/biom 11020321

Academic Editor: Jose Antonio Curiel

Received: 20 January 2021

Accepted: 17 February 2021

Published: 20 February 2021

Publisher's Note: MDPI stays neutral with regard to jurisdictional claims in published maps and institutional affiliations.

Copyright: (c) 2021 by the authors. Licensee MDPI, Basel, Switzerland. This article is an open access article distributed under the terms and conditions of the Creative Commons Attribution (CC BY) license (https:// creativecommons.org/licenses/by/ $4.0 /)$.

\begin{abstract}
A large proportion of broccoli biomass is lost during primary production, distribution, processing, and consumption. This biomass is rich in polyphenols and glucosinolates and can be used for the production of bioactive rich ingredients for food and nutraceutical applications. This study evaluated thermosonication (TS) $\left(18 \mathrm{kHz}, 0.6 \mathrm{~W} / \mathrm{g}, 40-60{ }^{\circ} \mathrm{C}, 3-7 \mathrm{~min}\right)$ for the pretreatment of broccoli florets to enhance enzymatic conversion of glucoraphanin into the bioactive sulforaphane. TS significantly increased sulforaphane yield, despite a decrease in myrosinase activity with increasing treatment intensity. The highest sulforaphane yield of $\sim 2.9$ times that of untreated broccoli was observed for broccoli thermosonicated for $7 \mathrm{~min}$ at $60{ }^{\circ} \mathrm{C}$, which was $15.8 \%$ higher than the corresponding yield for thermal processing without sonication (TP) at the same condition. This was accompanied by increase in the residual level of glucoraphanin ( $\sim 1.8$ and 2.3 time respectively after TP and TS at $60{ }^{\circ} \mathrm{C}$ for $7 \mathrm{~min}$ compared to control samples) indicating that treatment-induced release of bound glucoraphanin from the cell wall matrix and improved accessibility could be at least partially responsible for the enhanced sulforaphane yield. The result indicates the potential of TS for the conversion of broccoli biomass into high sulforaphane broccoli-based ingredients.
\end{abstract}

Keywords: broccoli; thermosonication; mild heat; sulforaphane; myrosinase; glucoraphanin

\section{Introduction}

A large amount of vegetable biomass is wasted during the primary production, distribution, processing, and consumption of vegetables. This includes the potentially edible parts of the plant left on the field in normal harvest practice, wastage in the fresh market due to postharvest quality deterioration, and trimmings produced during consumption and processing. A significant proportion of the produce is also deemed second grade i.e., not suitable for the premium market, especially in the developed world mainly due to cosmetic market specifications. Broccoli is among the vegetables with the highest wastage in Australia. Only 40\% of the broccoli plant material is harvested as the leaves and the stem are usually plowed back into the field or used as animal feed. Of the edible part, less than $50 \%$ is sold as a premium produce with 12 to $30 \%$ considered second grade and $28 \%$ wasted in the fresh market. In addition, of the $\sim 5 \%$ processed, up to $60 \%$ of the broccoli head, which includes the base material and the stem is discarded during processing [1]. This is a significant underuse of edible biomass since the broccoli plant including the stem and the leaves is a rich source of protein, fiber, and phytochemicals such as polyphenols and glucosinolates (GLSs) [2,3]. Glucosinolates in particular are unique to cruciferous vegetables such as broccoli and are associated with several health benefits. Consumption of GLSs derived bioactive compounds such as isothiocyanates reduce the risk of cancer [4] and lower cholesterol [5]. The most abundant GLS in broccoli is glucoraphanin (4-methylsulfinylbutyl glucosinolate, GR) which is biologically inactive [6]. Bioactive compounds are formed upon hydrolysis of GR by the enzyme myrosinase (thioglucoside glucohydrolase, EC 3.2.3.147). Sulforaphane, an isothiocyanate that is formed as a result of GR hydrolysis in broccoli [7], 
has been found to be a potent bioactive against cancer [8], diabetes [9], and obesity [10], among other conditions.

Myrosinases are present in plants containing GLSs [7,11]. However, the conversion of GR to bioactive compounds occurs only when plant tissues undergo disruption during processing, cutting, and/or chewing, as myrosinase and GR are present in different cell compartments in the intact plant [11,12]. The rate of hydrolysis and the concentration of various products resulting from hydrolysis of GR depends on the reaction conditions (e.g., temperature, $\mathrm{pH}$, ferrous ion concentrations) and presence of epithiospecifier protein (ESP) [13]. The production of sulforaphane (1-isothiocyanato-4-methylsulfinylbutane; SF) is favored at elevated temperature (above $50^{\circ} \mathrm{C}$ ) and natural $\mathrm{pH}$, while sulforaphane nitrile synthesis is favored at lower temperature (below $50^{\circ} \mathrm{C}$ ), acidic $\mathrm{pH}$, and the presence of ESP $[7,14-16]$.

Due to the interest in sulforphane as a health promoting bioactive, many studies have examined cooking and processing methods to optimize sulforphane formation in broccoli and broccoli sprouts [7,14,17-21]. Pérez et al. [17] reported a significant increase in SF content by heating between 50 and $60^{\circ} \mathrm{C}$, with the optimal yield after immersion in water at $57^{\circ} \mathrm{C}$ for $13 \mathrm{~min}$ and a decrease at higher temperatures $\left(70^{\circ} \mathrm{C}\right)$ due to thermal degradation of SF. Ghawi et al. [7] studied the effect of thermal processing $\left(30-100^{\circ} \mathrm{C}\right)$ on GR content, SF formation, and myrosinase activity in broccoli and reported significant increases in GR content after 4,8 , and $12 \mathrm{~min}$ heat treatment at $80^{\circ} \mathrm{C}$, and decrease in myrosinase activity at temperature $>50^{\circ} \mathrm{C}$. Despite reduced myrosinase activity at temperatures $>50^{\circ} \mathrm{C}$, the maximum SF formation was achieved after 8 and $12 \mathrm{~min}$ at $70{ }^{\circ} \mathrm{C}$. The increase in sulforaphane yield under mild heating condition is mainly attributed to the selective inactivation of ESP; the protein co-factor that mediates conversion to sulforaphane nitrile instead of sulforaphane [16,22], although some studies suggest an increase in extractable GR after thermal processing at temperature as high as $100{ }^{\circ} \mathrm{C}$. Nevertheless, the formation of SF is limited at temperatures $>70^{\circ} \mathrm{C}$ because of the sensitivity of both myrosinase and SF to thermal degradation $[7,17]$.

While most studies examined the effects of heat on SF content, there are opportunities for enhancing SF content by use of other pre-processing treatments. The use of ultrasound in combination with moderate thermal treatment is considered attractive as ultrasound is known to increase the extractability of components from plant matrices [23] as well as enhance the activity of some enzymes and enzyme-substrate interaction. Under mild temperature conditions, ultrasound may increase enzyme activity by facilitating mass transfer and micro-mixing [24], which facilitate enzyme-substrate interaction and in some cases through changes in the conformation of enzymes, which potentially expose more active sites [25].

To our knowledge there is no published work on the combined effect of thermal and ultrasound treatment on the extractability of GR, SF formation and myrosinase activity in broccoli. It is expected that the interplay of all these factors influence SF yield. We hypothesized that the combination of ultrasound and moderate heat (thermosonication) would be more effective than heat treatment alone for disrupting plant tissue. This would enhance release of GR and increase the accessibility of myrosinase to GR, facilitating contact between myrosinase and GR due to increased diffusivity of these components. However, how thermosoncation would affect the activity of myrosinase is unknown. The aim of this study was to investigate the feasibility of thermosonication treatments for maximizing $\mathrm{SF}$ yield in broccoli puree. The effect of thermosonication on myrosinase activity and the extractability of GR were also investigated and compared with thermal processing without sonication.

\section{Materials and Methods}

\subsection{Materials}

Chemicals were purchased from Sigma-Aldrich (Sigma-Aldrich, St Louis, MO, USA) or Merck (Darmstadt, Germany) and were of analytical or HPLC grade, unless stated other- 
wise. Market fresh broccoli (cv. 'Viper') samples of $\sim 15 \mathrm{~kg}$ ( 3 batches each $5 \mathrm{~kg}$ on different days for three different treatment groups) were purchased from a local supermarket (Coles, Werribee, Victoria, Australia) and were stored at $4{ }^{\circ} \mathrm{C}$ for a maximum of $2 \mathrm{~h}$ prior to use. For each treatment temperature, the respective thermal and thermosonication experiments were conducted using the same batch of broccoli.

\subsection{Preparation of Samples}

Broccoli heads were washed with tap water and the florets were cut into $2-3 \mathrm{~cm}$ length. For each experimental run, $75 \mathrm{~g}$ of broccoli florets was weighed in a $500 \mathrm{~mL}$ glass container and $250 \mathrm{~mL}$ Milli-Q water was added. This allowed full coverage of the florets with water. This was necessary to facilitate the thermosonication treatments as it enabled the immersion of the tip of the ultrasound sonotrode into the sample. This ratio of sample/Milli-Q water was chosen based on preliminary experiments as higher sample/water ratios resulted in more solids, less homogeneity and consequently inhomogeneous acoustic energy densities delivered to the samples. In contrast, lower sample to water ratios led to over dilution of samples for adequate conversion into sulforaphane (data not shown). However, the results of the analyzed parameters following treatments were expressed on the basis of dry weight of the samples; calculated based on the moisture content of the samples (samples contained $3.04 \%$ dry matter) measured using a HR73 Halogen Moisture Analyzer (Mettler Toledo Ltd., Victoria, Australia).

\subsection{Thermosonication and Thermal Treatments}

The thermosonication experiments were conducted using an $18 \mathrm{kHz}$ ultrasonic processor (UP500S, $500 \mathrm{~W}$, Hielscher Ultrasonics, Teltow, Germany) with a titanium sonotrode (tip diameter $18 \mathrm{~mm}$, length $70 \mathrm{~mm}$ ). Due to an increase in the temperature during sonication, broccoli floret samples prepared as described in Section 2.2 were placed into a chamber with a water circulation system to maintain temperature at the target experimental temperature. Changes in temperature were monitored with a digital thermometer during the process. The maximum deviation from the target experimental temperature was $2{ }^{\circ} \mathrm{C}$. The sonotrode was submerged $\sim 3 \mathrm{~cm}$ into the samples and the process was carried out at an ultrasonic power density of $0.60 \pm 0.03 \mathrm{~W} / \mathrm{g}$ for 3,5 , and $7 \mathrm{~min}$ at 40,50 , and $60^{\circ} \mathrm{C}$. A schematic diagram of the experimental set up is shown in Figure 1. Before treatment, samples were pre-heated to the experimental temperature in a thermostated water bath maintained at 50,60 , and $70{ }^{\circ} \mathrm{C}$ for about $10 \mathrm{~min}$, for target temperatures of 40,50 , and $60{ }^{\circ} \mathrm{C}$ respectively. Samples were immersed in ice-water immediately after processing. For calculation of acoustic energy densities delivered to the samples, the following formula was used [26]:

$$
I=\frac{P}{W}
$$

where $P$ is ultrasound power $(\mathrm{W}), W$ is the weight of sample $(\mathrm{g})$, and $I$ is acoustic energy density $(\mathrm{W} / \mathrm{g})$. The actual power input during the sonication treatment was measured using a power meter (Watts Clever EW-AUS5001, Frankston, Australia) connected to the electric power outlet. Thermal treatment experiments were conducted for comparison at the same temperatures in a thermostated water bath. The temperature/times used were 40 , 50 or $60^{\circ} \mathrm{C}$ for 3,5 or $7 \mathrm{~min}$. Timing started after the florets reached the experimental temperature. Samples were cooled in ice-water immediately after processing. All experiments were conducted in triplicates. 


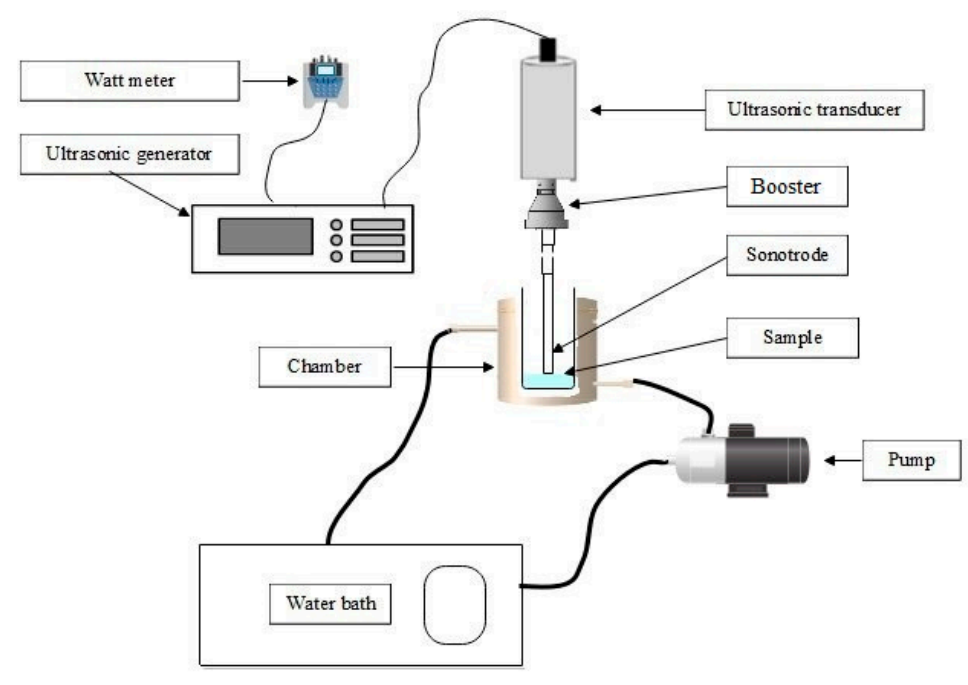

Figure 1. A schematic diagram of the thermosonication treatment set up.

\subsection{Broccoli Puree Processing}

Following thermosonication or thermal treatments, samples $(75 \mathrm{~g}$ broccoli in $250 \mathrm{~mL}$ Milli-Q water) were pureed using a kitchen scale blender (Nutribullet pro 1200 series, LLC, Capital brands, Los Angeles, CA, USA). The purees were incubated for $2 \mathrm{~h}$ at $30^{\circ} \mathrm{C}$ to allow myrosinase to hydrolyze glucoraphanin. Sub-samples were aliquoted for glucoraphanin and sulforaphane analysis and were frozen immediately and kept frozen at $-18{ }^{\circ} \mathrm{C}$ until analyses. Sub-samples aliquoted for myrosinase activity assay were freeze-dried.

\subsection{Glucoraphanin Extraction and Analysis}

For the extraction of GR, two methods were initially examined: aqueous extraction or methanolic extraction. Previously, both water [27] and methanol [19] have been used for GR extraction. In the present study we wanted to compare the effects of using different extraction solvents to evaluate whether levels of extractable GR were influenced by the type of solvent.

\subsubsection{Aqueous Extraction}

The water extracts of broccoli samples were prepared according to the method previously described by Cai et al. [27] with some modifications. Four grams of frozen broccoli puree was mixed with $5 \mathrm{~mL}$ of boiling Milli-Q water and vortexed for $1 \mathrm{~min}$. The mixture was then incubated in a boiling water bath for $5 \mathrm{~min}$. After cooling in ice, samples were centrifuged at $5000 \times g$ for $15 \mathrm{~min}$ at $10^{\circ} \mathrm{C}$. Supernatants were collected and a second extraction of the residue was conducted with $5 \mathrm{~mL}$ of boiling Milli-Q water and the supernatant was collected. Finally, the supernatants were combined and evaporated to dryness with a vacuum spin dryer (SC250EXP, Thermo Fisher Scientific, CA, USA) at ambient temperature $\left(\sim 22{ }^{\circ} \mathrm{C}\right)$. Dried samples were dissolved appropriately in a solvent (acetonitrile/water $(85: 15, v / v)$ with $30 \mathrm{mM}$ ammonium formate), filtered through a $0.22 \mu \mathrm{m}$ membrane filter (Merck Millipore, Billerica, MA, USA) and analyzed by HPLC.

\subsubsection{Methanolic Extraction}

The methanol extracts were prepared according to the method described by Pongmalai et al. [19] with some modifications. Ten grams of each sample was mixed with $17.96 \mathrm{~mL}$ of pre-heated methanol $\left(70^{\circ} \mathrm{C}\right)$ to obtain a 70:30 $\mathrm{v} / \mathrm{v}$ methanol: water ratio. The mixture was then blended using an Ultra-Turrax T25 (JANKE and KUNKEL; IKA Labortechnik, Staufen, Germany) for one minute at $13,500 \mathrm{rpm}$. This was followed by incubation in a recirculating water bath (Thermoline, Wetherill Park, NSW, Australia) maintained at $70{ }^{\circ} \mathrm{C}$ for $30 \mathrm{~min}$ under continuous stirring at $100 \mathrm{rpm}$. Samples were then cooled in ice-water, centrifuged $\left(5000 \times \mathrm{g} / 15 \mathrm{~min} / 4^{\circ} \mathrm{C}\right)$, and the supernatants were collected. The extraction was repeated 
twice. The supernatants were combined and the solvent was removed using vacuum spin dryer (SC250EXP, Thermo Fisher Scientific, Waltham, MA, USA) at ambient temperature $\left(\sim 22^{\circ} \mathrm{C}\right)$. The residue was dissolved appropriately in solvent (acetonitrile/water (85:15, $v / v$ ) with $30 \mathrm{mM}$ ammonium formate), filtered through a $0.22 \mu \mathrm{m}$ membrane filter (Merck Millipore, Billerica, MA, USA) and analyzed by a HPLC method.

\subsubsection{Analysis and Quantification of Glucoraphanin}

Quantification of glucoraphanin was carried out by using an Alliance HPLC instrument (Waters Corporation, Milford, MA, USA) equipped with Photo Diode Array Detector 2998 in accordance with the method of Cai et al. [27] with some modifications. A HPLC column-Luna ${ }^{\circledR} 3 \mu \mathrm{M}$ Hydrophilic Interaction Liquid Chromatography (HILIC) $200^{\circ} \mathrm{A}$ $(100 \times 4.6 \mathrm{~mm}$; Phenomenex, Torrance, CA, USA) was used for the analysis at a column temperature of $25^{\circ} \mathrm{C}$. The mobile phase consisted of an acetonitrile/water $(85: 15, v / v)$ with $30 \mathrm{mM}$ ammonium formate (solution A) and acetonitrile (solution B) with the following isocratic flow program: solution A 70\%; solution B 30\%. Other chromatographic conditions included a constant flow rate of $2.0 \mathrm{~mL} / \mathrm{min}$, an injection volume of $100 \mu \mathrm{L}$, a run time of $8 \mathrm{~min}$, and detection wavelength of $235 \mathrm{~nm}$. The identification of the glucoraphanin peak was based on the retention time and the chromatographic spectra of an authentic glucoraphanin standard. The concentrations of glucoraphanin were calculated using a standard curve developed with a glucoraphanin standard (Cayman Chemical Company, Ann Arbor, MI, USA) and was expressed as micrograms per gram dry weight ( $\mu \mathrm{g} / \mathrm{g} \mathrm{DW})$ of broccoli. The results were expressed as normalized glucoraphanin content by dividing the glucoraphanin amount after thermal or thermosonication treatment by glucoraphanin amount in untreated samples. The results were normalized as there was batch to batch variation in broccoli composition.

\subsection{Sulforaphane Extraction and Analysis}

\subsubsection{Extraction}

The extraction and analysis of sulforaphane was conducted as described in Cai et al. [28] with some modification. Briefly, $4 \mathrm{~g}$ of frozen sample was mixed with $2 \mathrm{~mL}$ of Milli-Q water and vortexed for $1 \mathrm{~min}$. Then, $20 \mathrm{~mL}$ of ethyl acetate was added and the mixture was sonicated using a sonication bath (IDK technology Pty Ltd., VIC, Australia) for 5 min followed by shaking for $20 \mathrm{~min}$ at $4{ }^{\circ} \mathrm{C}$. The mixture was centrifuged at $5000 \times g$ for $15 \mathrm{~min}$ at $10^{\circ} \mathrm{C}$ and the supernatant was collected. A second extraction was carried out by adding $15 \mathrm{~mL}$ ethyl acetate to the residue. The supernatants from the two extractions were combined and dried using a vacuum spin dryer (SC250EXP, Thermo Fisher Scientific, Waltham, MA, USA) at room temperature $\left(22^{\circ} \mathrm{C}\right)$. All samples were dissolved appropriately in $30 \%$ acetonitrile, filtered through a $0.22 \mu \mathrm{m}$ membrane filter (Merk Millipore, Billerica, MA, USA) and analyzed by UPLC.

\subsubsection{Analysis and Quantification}

The sulforaphane content of the samples was analyzed using an Acquity ${ }^{\mathrm{TM}}$ Ultra Performance liquid chromatography (UPLC) system (Waters Corporation, Milford, MA, USA), which is equipped with a binary solvent delivery manager and a sample manager. Chromatographic separations were performed on a $2.1 \mathrm{~mm} \times 50 \mathrm{~mm}$, Acquity BEH C18 chromatography column. The mobile phase A and B were $0.1 \%$ Formic acid in Milli-Q water and $0.1 \%$ Formic acid in acetonitrile, respectively. The gradient elution system consisted of mobile phase A (0.1\% Formic acid in Milli-Q water) and B ( $0.1 \%$ Formic acid in acetonitrile) and separation was achieved using the following gradient: $0-2 \mathrm{~min}, 10 \% \mathrm{~B} ; 2-5 \mathrm{~min}, 20 \%$ B; 5-10 min, $10 \% \mathrm{~B}$. The column temperature was kept constant at $30{ }^{\circ} \mathrm{C}$. The flow rate was $0.350 \mathrm{~mL} / \mathrm{min}$ and the injection volume was $10 \mu \mathrm{L}$. The concentration of sulforaphane was calculated based on a standard curve developed with an authentic sulforaphane standard (DL-sulforaphane, Sigma-Aldrich, St. Louis MO, USA), and the results were expressed as micrograms per gram dry weight (DW) $(\mu \mathrm{g} / \mathrm{g} D W)$ of broccoli. The results were reported 
as normalized sulforaphane content by dividing measured sulforaphane concentration after thermal or thermosonication treatment by measured sulforaphane concentration in untreated samples to allow for comparisons between different batches of broccoli samples.

\subsection{Determination of Myrosinase Activity}

\subsubsection{Myrosinase Extraction}

Myrosinase extraction was conducted following the method described by Ghawi et al. [7] with modification. Briefly, $500 \mathrm{mg}$ freeze-dried broccoli powder was suspended in $15 \mathrm{~mL}$ sodium phosphate buffer (100 mM, pH 6.5) and blended using an Ultra-Turrax T25 (JANKE and KUNKEL; IKA Labortechnik, Staufen, Germany) at 13,500 rpm for $1 \mathrm{~min}$. The mixture was stirred for $1 \mathrm{~h}$ at $4{ }^{\circ} \mathrm{C}$ and then centrifuged at $10,000 \times g$ for $15 \mathrm{~min}$ at $4{ }^{\circ} \mathrm{C}$. The supernatant was recovered and was subjected to ammonium sulfate precipitation at $80 \%$ saturation. The precipitate was dissolved in $1 \mathrm{~mL}$ sodium phosphate buffer $(100 \mathrm{mM}$ $\mathrm{pH}$ 6.5) and used as enzyme extract for myrosinase activity assay.

\subsubsection{Myrosinase Activity Assay}

Myrosinase activity was determined as the amount of glucose released from the hydrolysis of sinigrin by myrosinase after $15 \mathrm{~min}$ incubation at $30^{\circ} \mathrm{C}[7,19]$. One $\mathrm{mL}$ reaction mixture containing $250 \mu \mathrm{L}$ enzyme extract, $750 \mu \mathrm{L}$ sodium phosphate buffer $(100$ $\mathrm{mM}, \mathrm{pH}$ 6.5), $1 \mathrm{mM}$ EDTA, $3 \mathrm{mM} \mathrm{MgCl}$, and $1 \mathrm{mM}$ sinigrin as substrate was prepared. All chemicals were purchased from Sigma (St. Louis, MO, USA). After incubation at $30^{\circ} \mathrm{C}$ for $15 \mathrm{~min}$ the reaction was stopped by placing samples in boiling water $\left(100^{\circ} \mathrm{C}\right)$ for $5 \mathrm{~min}$. The mixture was centrifuged at $25,000 \times \mathrm{g}$ for $10 \mathrm{~min}$ at $4{ }^{\circ} \mathrm{C}$ and the amount of glucose released was quantified using Glucose (HK) assay kit (Sigma, St. Louis, MO, USA) according to the procedure provided in the kit. One unit of myrosinase activity was defined as microgram glucose per min released during the myrosinase catalyzed hydrolysis of sinigrin under the assay condition. The result was presented as relative activity of myrosinase i.e., (A/Ao) with A denoting myrosinase activity after thermal or thermosonication treatment and Ao denoting myrosinase activity in the untreated sample.

\subsection{Statistical Analysis}

Statistical analysis of the data was performed using SPSS (version 18.0 for Windows, SPSS, Inc., Chicago, IL, USA) software and mean value \pm standard deviation of three replications were reported. The data normality and homogeneity of variances were tested using Shapiro-Wilk's and the Levene's tests, respectively. Significant differences in mean values were calculated using Duncan's post hoc test. Differences between mean values were considered significant at $p<0.05$.

\section{Results and Discussion}

\subsection{The Stability of Broccoli Myrosinase Subject to Thermosonication and Thermal Processing}

The effects of thermal and thermosonication treatments on the activity of broccoli myrosinase are presented in Figure 2. The initial amount of myrosinase activity was on average $88.7 \mathrm{U} / \mathrm{g}$ DW for batch 1, $89.3 \mathrm{U} / \mathrm{g}$ DW for batch 2, and $110.9 \mathrm{U} / \mathrm{g}$ DW for batch 3 broccoli samples (Table S1 in the Supplementary Materials). There was a significant batch to batch variation in the myrosinase activity of the broccoli samples. The thermal inactivation of broccoli myrosinase commenced at $40{ }^{\circ} \mathrm{C}$ with $4.9,2.4$ and $3.2 \%$ inactivation after 3,5 or 7 min heating, respectively, compared to untreated broccoli $(p<0.05)$. This is in agreement with the results of Ghawi et al. [7] who reported that the inactivation of myrosinase in broccoli was initiated at $40{ }^{\circ} \mathrm{C}$, and its activity decreased by more than $80 \%$ after $12 \mathrm{~min}$ at $60{ }^{\circ} \mathrm{C}$ with the activity completely lost after heating at $80^{\circ} \mathrm{C}$ for $12 \mathrm{~min}$. As would be expected, the degree of myrosinase inactivation increased with increase in temperature and treatment time. Thermal treatment at $50{ }^{\circ} \mathrm{C}$ and $60{ }^{\circ} \mathrm{C}$ decreased myrosinase activity by $14.9-23.8 \%$ and $35.4-59.3 \%$ respectively compared to untreated broccoli, depending on 
duration of thermal treatment (Figure 2). Under the conditions examined, the maximum inactivation was observed after $7 \mathrm{~min}$ heating at $60^{\circ} \mathrm{C}(59.3 \%$ decrease).

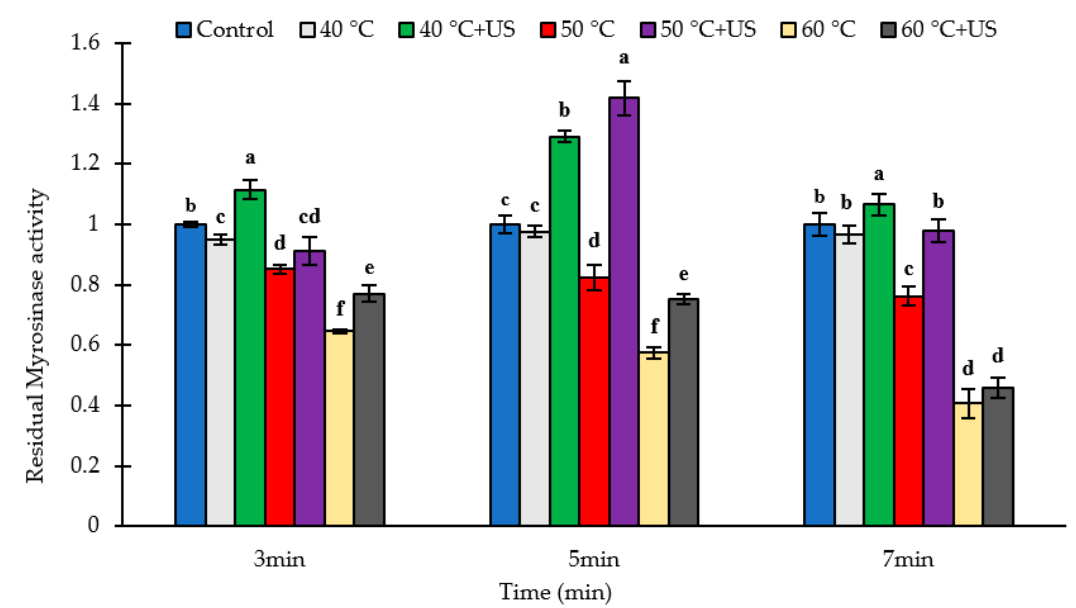

Figure 2. The residual activity of myrosinase in broccoli puree after thermal/thermosonication pre-treatments of broccoli floret. Letters above each bar indicate the results of Duncan's test; Different letters within the same group indicate significant difference $(p<0.05)$.

In contrast, thermosonication treatment at $40{ }^{\circ} \mathrm{C}$ for various times led to significant increases $(p<0.05)$ in myrosinase activity of $6.6-29.1 \%$ compared to untreated broccoli. The impact of thermosonication treatment at $50{ }^{\circ} \mathrm{C}$ was dependent on the treatment time; 5 min treatment resulted in a $\sim 40 \%$ higher $(p<0.05)$ myrosinase activity compared to control whereas $3 \mathrm{~min}$ treatment resulted in a slight decrease in activity $(p<0.05)$ with no difference in activity observed between the control and samples treated for 7 min (Figure 2). On the other hand, thermosonication treatments at $60^{\circ} \mathrm{C}$ resulted in a slight but significant $(p<0.05)$ decrease in the activity of myrosinase compared to the untreated control for all treatment times. However, the level of activity decrease after thermosoncation at $60^{\circ} \mathrm{C}$ was significantly lower $(p<0.05)$ than those observed for the corresponding thermal treatments at the same time/temperature condition except for the $7 \mathrm{~min}$ treatment. The residual myrosinase activity in samples thermosonicated at $60{ }^{\circ} \mathrm{C}$ for $7 \mathrm{~min}$ was $5.4 \%$ higher than the corresponding values for thermally treated samples at the same condition, although the difference was not statistically significant $(p>0.05)$.

There are conflicting reports on the thermal stability of broccoli myrosinase, partly due to the difference in the media in which the studies are conducted, varietal differences and the method of heat treatment. Ludikhuyze et al. [29] reported that broccoli myrosinase inactivation in a buffer system ( $0.1 \mathrm{M}$ phosphate buffer at $\mathrm{pH} 6.55$, which corresponds to the $\mathrm{pH}$ of the fresh broccoli juice) started at $30^{\circ} \mathrm{C}$ and more than $90 \%$ of the activity was lost after $3 \mathrm{~min}$ treatment at $60^{\circ} \mathrm{C}$. Van Eylen et al. [22] reported that broccoli myrosinase was stable until $45^{\circ} \mathrm{C}$, when vacuum packed broccoli heads were heated in a water bath, and its activity was reduced by more than $95 \%$ after a $10 \mathrm{~min}$ treatment at $70{ }^{\circ} \mathrm{C}$. Ghawi et al. [7] studied the effect of thermal treatments $\left(30-100^{\circ} \mathrm{C}\right)$ using the sous vide cooking method on myrosinase activity in broccoli heads and observed more than $80 \%$ loss after $4 \mathrm{~min}$ at $90{ }^{\circ} \mathrm{C}$, and only $6 \%$ residual activity after $8 \mathrm{~min}$ at $80{ }^{\circ} \mathrm{C}$. Contrary to previous studies, Pérez et al. [17] reported a significant increase in myrosinse activity in broccoli floret during blanching by putting broccoli florets directly into a thermostatic bath containing deionized water at temperatures ranging from $46-74{ }^{\circ} \mathrm{C}$ for 3-17 min with the maximum activity observed after heating at $70{ }^{\circ} \mathrm{C}$ for $17 \mathrm{~min}$. They attributed that to the increased extractability of myrosinase with increase in blanching temperatures.

An interesting result in our study was that there was in general higher residual myrosinase activity in broccoli samples subjected to thermosonication compared to the corresponding heated samples, with few exceptions where the difference was not statis- 
tically significant. While thermosonication treatment using low frequency high intensity ultrasound might be expected to cause a higher level of inactivation of enzymes compared to thermal treatment alone [25], other factors including the intensity of the ultrasonic treatment and the effects of ultrasound on the plant matrix can impact the observed effect on enzyme activity. Ultrasound can have dual effects on enzyme activity in tissue systems. On one hand, the strong shear force generated during acoustic cavitation produces mechanical disruption of the broccoli matrix and cell damage with the consequent release of myrosinase from myrosin cells [18] resulting in increased activity. On the other hand, the extreme localized increase in temperature $(500 \mathrm{~K})$ and pressure $(50 \mathrm{MPa})$, the strong shear and microstreaming and the generation of free radicals that accompany cavitation can cause changes in the structure and conformation of enzymes leading to inactivation [25]. Synergistic inactivation of enzymes by ultrasound combined with mild heat has been reported in several studies $[23,25,30]$. The measured enzyme activity depends on whether extraction or inactivation is the dominant effect. Thus, the observed higher residual myrosinase activity in the sonicated samples does not necessarily imply that thermosonication has less inactivating effect on myrosinase compared to thermal treatment under the corresponding heat treatment conditions, rather sonication induced enhanced extraction is possibly the dominant effect.

\subsection{Effect of Thermosonication and Heat on Sulforaphane Yield}

The effects of thermal treatment $\left(40,50\right.$, or $60^{\circ} \mathrm{C}$ for 3,5 , or $\left.7 \mathrm{~min}\right)$ and thermosonication $(18 \mathrm{kHz})$ on the yield of the bioactive sulforaphane (SF) in broccoli puree after incubation for $2 \mathrm{~h}$ at $30^{\circ} \mathrm{C}$ are presented in Figure 3 and Table S1 of the Supplementary Materials. The SF content in non-treated broccoli puree were on average $195.9 \mu \mathrm{g} / \mathrm{g} \mathrm{DW}$, $180.6 \mu \mathrm{g} / \mathrm{g}$ DW and $592.1 \mu \mathrm{g} / \mathrm{g}$ DW for batch 1, batch 2 and batch 3 samples respectively (Table S1 in Supplementary Materials). The higher level of sulforaphane in the untreated batch 3 samples could be due to the higher myrosinase activity in this sample (Section 3.1.). Heating alone for 3,5 , and $7 \mathrm{~min}$ at $40{ }^{\circ} \mathrm{C}$ increased SF by $12.9,31.7$, and $26.0 \%$ respectively, compared to raw broccoli, although the increase for 3 min treatment was not statistically significant $(p>0.05)$. Thermal treatment at $50^{\circ} \mathrm{C}$ or $60^{\circ} \mathrm{C}$ for 3,5 or $7 \mathrm{~min}$ significantly increased $(p<0.05) \mathrm{SF}$ yield when compared to untreated broccoli. The SF contents were 68.1-152.6\% higher after treatment at $60^{\circ} \mathrm{C}$ compared to the untreated control whereas the SF contents were 59 to $128 \%$ higher than control in the case of the $50{ }^{\circ} \mathrm{C}$ heat treatments. Nevertheless, the difference in the relative increase of sulforaphane content between 50 and $60^{\circ} \mathrm{C}$ was not statistically significant (Figure 3 ). The maximum SF concentration among the studied conditions was achieved after 7 min heat treatment at $60{ }^{\circ} \mathrm{C}$ (Table S1). This may not represent the absolute maximum since increase in treatment time or temperature may result in a higher sulforaphane yield, although earlier studies [7] indicate that longer treatments at $60^{\circ} \mathrm{C}$ may result in substantial inactivation of myrosinase and hence lower sulforaphane yield.

Except in some cases such as $40^{\circ} \mathrm{C}$ for $3 \mathrm{~min}$ (Figure 3), thermosonication increased SF yield by $36.7-192.6 \%$ compared to untreated samples and $5.06-40.0 \%$ in comparison to corresponding heat-treated samples without ultrasound, although the difference between the two was statistically significant only for the $3 \mathrm{~min}$ treatment at $50{ }^{\circ} \mathrm{C}$ and the $7 \mathrm{~min}$ treatment at $60^{\circ} \mathrm{C}$. The maximum SF content among the studied conditions was achieved using thermosonication treatment at $60{ }^{\circ} \mathrm{C}$ for $7 \mathrm{~min}$, which represented a $192.6 \%$ increase compared to untreated broccoli florets. That was $15.8 \%$ higher than the corresponding thermal treatment indicating the potential of thermosonication for enhancing sulforaphane yield over and above the effect of heat. Further increase in treatment temperature or time may result in higher sulforaphane yield, although inactivation of myrosinase under more intense thermosonication condition may have the opposite effect. Notwithstanding, further optimization of the thermosonication treatment condition is required in order to realize the full potential of the technology and confirm indeed whether the technology enables better sulforaphane yield compared to thermal treatment alone. 


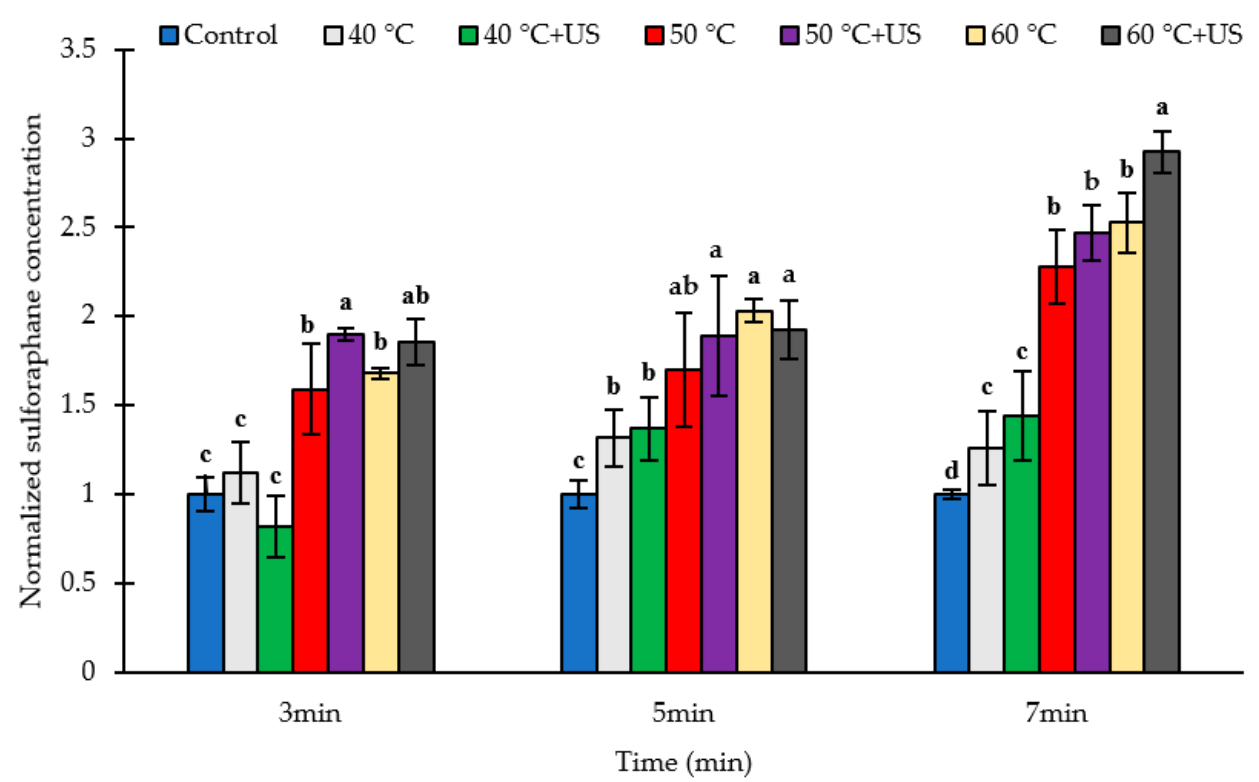

Figure 3. The normalized sulforaphane yield (Sulforaphane content in treated sample/sulforaphane content in untreated control) in broccoli puree after thermal/thermosonication pre-treatments of broccoli floret. Letters above each bar indicate the results of Duncan's test; Different letters within the same group indicate significant difference $(p<0.05)$.

From the results it is evident that thermal treatment at 50 to $60{ }^{\circ} \mathrm{C}$ significantly increases the SF content in broccoli. In agreement with these observations, Ghawi et al. [7] reported SF formation in broccoli floret increased by 6 times compared to the raw samples, after heating for $12 \mathrm{~min}$ at $70^{\circ} \mathrm{C}$, where they used the sous vide cooking method for thermal treatment of broccoli florets. Similar findings were reported by Sarvan et al. [31], Bello et al. [14], Pongmalai et al. [19], Pongmalai et al. [18], and Pérez et al. [17]. Increase in SF content in broccoli subjected to mild heat treatment is commonly attributed to thermal inactivation of the thermolabile epithiospecifier protein (ESP), which acts as non-catalytic cofactor for myrosinase that promotes the formation of SF-nitrile from GR instead of SF [11]. Matusheski et al. [15] observed a significant inactivation of ESP in broccoli after 5 and 10 min heating at $40{ }^{\circ} \mathrm{C}$ and $50^{\circ} \mathrm{C}$, respectively, and complete inactivation after 5 min heating at $60^{\circ} \mathrm{C}$, which was accompanied by higher $\mathrm{SF}$ formation. Nevertheless, the heat-induced increase in extractability and accessibility of GR [7] may also contribute to the observed higher yield of SF in mild-heat-treated broccoli. The results of this study also showed the potential of thermosonication to enhance SF yield in broccoli puree over and above the effects of mild heat. This could be due to cavitation induced cell disruption that facilitate the release and accessibility of glucoraphanin and subsequent myrosinase-glucoraphanin interaction. As discussed in Section 3.3 below, ultrasound results in higher amount of extractable GR, indicating that the treatment results in increased GR release, and improved accessibility for interaction with myrosinse, resulting in higher SF production.

It is important to note that sulforaphane yield did not correlate with the degree of inactivation of myrosinase and the remaining residual activity. On the contrary, higher sulforaphane yield was observed under conditions of significant myrosinase inactivation. This could be attributed to the inactivation of ESP, thus providing a suitable condition for the synthesis SF from GR as opposed to SF-nitrile and/or increased in situ residual myrosinase activity at elevated temperatures [20] and increased release and accessibility of GR. In agreement with our results, Sarvan et al. [31] observed a significantly higher SF content in broccoli florets after 2 min steaming (about $85^{\circ} \mathrm{C}$ ) compared to raw broccoli samples, although the residual myrosinase activity was only $2.5 \%$. 


\subsection{Effect of Heat and Thermosonication Treatments on Glucoraphanin Content}

The GR content of aqueous and methanolic extracts of untreated broccoli florets after pureeing and incubation were on average $355.5 \pm 15.2$ and $405.2 \pm 41.9 \mu \mathrm{g} / \mathrm{g}$ DW respectively (Table S1 in Supplementary Materials), which was a significant decrease compared to the typical amount of $\sim 1500 \mu \mathrm{g} / \mathrm{g}$ DW or $\sim 3.4 \mu \mathrm{mol} / \mathrm{g}$ DW for intact broccoli florets from the same source observed in our previous studies $[28,32]$. The glucoraphanin content of broccoli is dependent on factors such as cultivar and growing condition and the reported values range from 0.3 to $38.4 \mu \mathrm{mol} / \mathrm{Kg}$ DW [33]. For instance, Pérez, et al. [17] reported $\sim 12.6 \mu \mathrm{mol} / \mathrm{g}$ DW, Jones et al. [34] reported $28.6 \mu \mathrm{mol} / \mathrm{g}$ DW for Marathon cultivar and $13.1 \mu \mathrm{mol} / \mathrm{g}$ DW for Booster ${ }^{\mathrm{TM}}$ cultivar and Sarvan et al. [35] reported 181 $\mu \mathrm{mol} / 100 \mathrm{~g}$ fresh weight (equivalent to $18.1 \mu \mathrm{mol} / \mathrm{g} \mathrm{DW}$ ). The significant decrease in GR content of broccoli after pureeing and incubation could be attributed to enzymatic conversion of GR into sulforaphane and other metabolites. Glucosinolates including GR may undergo non-enzymatic degradation and conversion at acidic, alkaline, or extreme heat $\left(>100{ }^{\circ} \mathrm{C}\right)$ conditions or in the presence of certain chemicals [36]. However, at the natural $\mathrm{pH}$ of broccoli and under mild processing conditions as in this study, the main mechanism of degradation is enzymatic hydrolysis mainly to sulforaphane or sulforaphane nitrile in the presence of active ESP [33]. The difference between the GR content of aqueous and methanolic extracts was not statistically significant $(p>0.05)$. The relative changes in the concentrations of aqueous and methanolic extracts of glucoraphanin (GR) after thermal and thermosonication treatments followed by pureeing and incubation are shown in Figure 4a,b, respectively. A significant amount of unconverted glucoraphanin remained in all the samples, possibly due to incomplete conversion during the short incubation time in addition to increased release of glucoraphanin from broccoli tissue counteracting the effect of GR conversion.

The measured residual GR content of broccoli samples after heat treatment for 3 or 5 min at $40{ }^{\circ} \mathrm{C}$ were slightly lower than untreated samples; although these differences were statistically significant $(p<0.05)$ only for the 3 min treatment. Similarly, treatments at 50 or $60^{\circ} \mathrm{C}$ for $3 \mathrm{~min}$ did not have significant effects on GR content of broccoli samples ( $p$ $>0.05$ ), while other thermal treatment conditions increased the measured residual level of GR significantly $(p<0.05)$ compared to untreated samples. This is despite the higher sulforaphane yield compared to control under these conditions (Figure 3), indicating that heat treatment enhances the release, extractability and subsequent accessibility of glucoraphanin for enzymatic conversion.

With regard to thermosonication, a significant increase in the residual content of GR compared to the untreated samples was observed except for the treatments at $40{ }^{\circ} \mathrm{C}$ for $3 \mathrm{~min}$ (Figure $4 \mathrm{a}, \mathrm{b})$. The residual level of GR, after 5 or $7 \mathrm{~min}$ thermosonication at $50{ }^{\circ} \mathrm{C}$ were $56.2 \%$ and $103.2 \%$ higher $(p<0.05)$ respectively than those in control. The highest residual level of GR was observed after thermosonciation at $60^{\circ} \mathrm{C}$ for $7 \mathrm{~min}(126.3 \%$ increase) followed by those that were thermosonicated at $50{ }^{\circ} \mathrm{C}$ for $7 \mathrm{~min}(103.6 \%$ increase compared to untreated samples), with no statistically significant difference between the two. Interestingly, the highest level of conversion to sulforaphane also occurred in samples that were thermosonicated for $7 \mathrm{~min}$ at $60{ }^{\circ} \mathrm{C}$. Despite this high level of conversion to sulforaphane, there was substantial amount of glucoraphanin $(837.7 \mu \mathrm{g} / \mathrm{g}$ DW or 1.9 $\mu \mathrm{mol} / \mathrm{g}$ DW) remaining in the samples, which is more than $56 \%$ of the typical measurable glucoraphanin content in intact broccoli florets $(\sim 1500 \mu \mathrm{g} / \mathrm{g}$ DW or $3.4 \mu \mathrm{mol} / \mathrm{g}$ DW) of the same type as mentioned above. The sulforaphane yield in samples thermosonicated for $7 \mathrm{~min}$ at $60^{\circ} \mathrm{C}$ was $1734.0 \mu \mathrm{g} / \mathrm{g}$ DW or $9.8 \mu \mathrm{mol} / \mathrm{g}$ DW. Assuming 1 to 1 stochiometric conversion of glucoraphanin to sulforaphane, the maximum level of sulforaphane that can be produced based on the typical measurable level of glucoraphanin in intact broccoli floret is $\sim 3.4 \mu \mathrm{mol} / \mathrm{g}$ DW. In this case, $9.8 \mu \mathrm{mol} / \mathrm{g}$ DW was observed, which is about 2.9 times more while about $1.9 \mu \mathrm{mol} / \mathrm{g}$ DW glucoraphanin remained unconverted in the sample. This indicates that the total amount of glucoraphanin in the broccoli sample is at least $11.7 \mu \mathrm{mol} / \mathrm{g}$ DW i.e., $9.8 \mu \mathrm{mol} / \mathrm{g}$ DW which was converted to sulforaphane 
plus $1.9 \mu \mathrm{mol} / \mathrm{g}$ DW glucoraphanin that remained in the sample. It can be concluded that (1) the measured level of glucoraphanin in untreated broccoli using current methods gives only an indication of the amount of easily accessible and extractable glucoraphanin in broccoli, and (2) processing of broccoli by heat and ultrasound enables the release of possibly bound glucoraphanin and enhance conversion to sulforaphane. A high degree of correlation ( $\mathrm{r}=0.77-0.84$ based on aqueous extraction) was observed between residual GR and SF contents in the processed samples, indicating the importance of accessible GR on SF yield. Further studies on the impact of thermal and ultrasonic processing on the extraction yield of glucoraphanin under conditions that inhibit myrosinase catalyzed conversion would enable a better understanding of the impact of these processes on the extractability of glucoraphanin and its consequence on myrosinase-glucoraphanin interaction and sulforaphane yield.

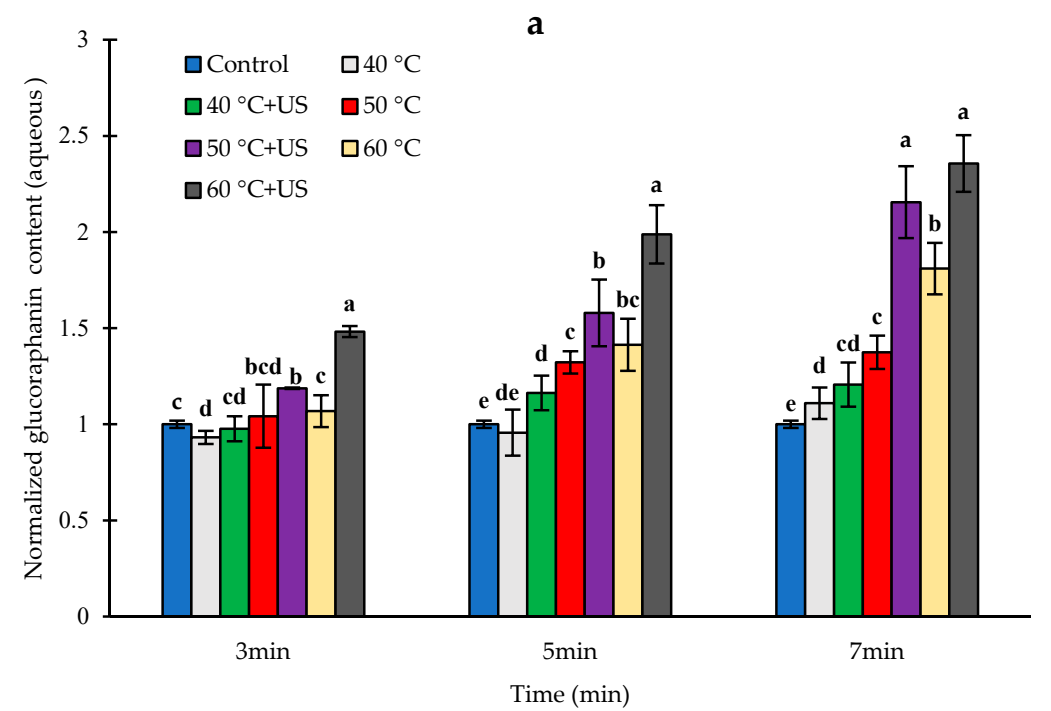

b

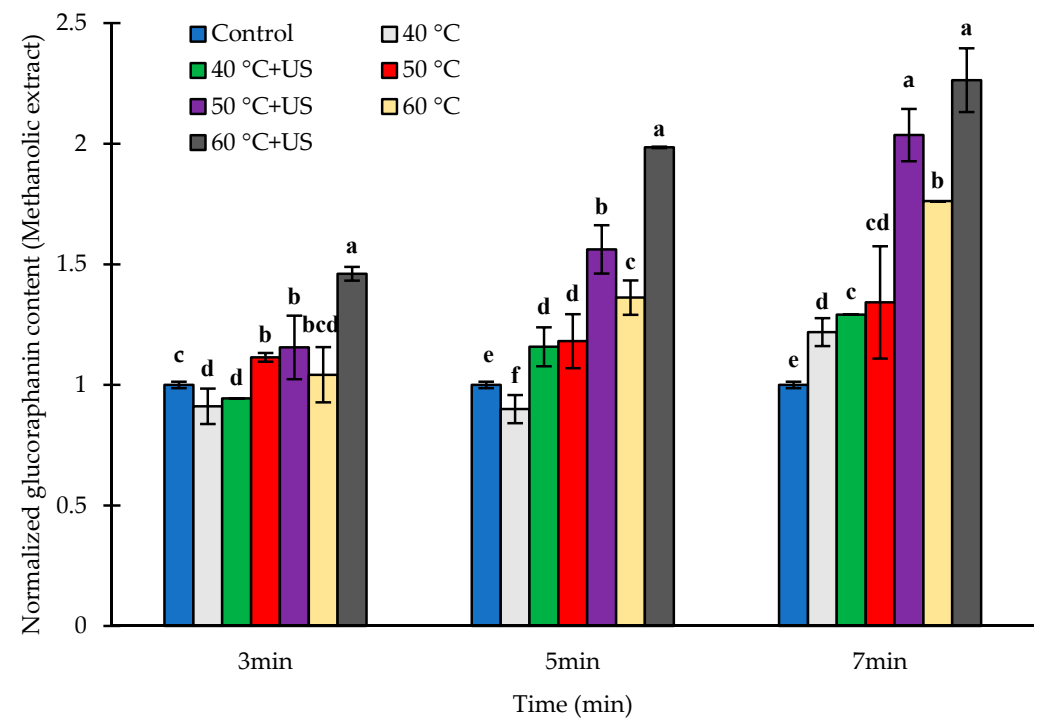

Figure 4. The normalized residual level of glucoraphanin contents (glucoraphanin content in treated samples/glucoraphanin content in untreated control) in aqueous (a) and methanolic (b) extracts from broccoli puree after thermal/thermosonication pre-treatments of broccoli florets and conversion to sulforaphane. Letters above each bar indicate the results of Duncan's test; Different letters within the same group indicate significant difference $(p<0.05)$. 
The observed increase in GR extractability with increasing temperature of heat treatment of broccoli florets can be attributed mainly to heat-induced structural modification of the broccoli matrix, which facilitates the release of GR [7,17,19,37]. Živković et al. [36] suggested that at elevated temperatures, there is degradation of plant matrix and cellular structures, which increases cell permeability.

In agreement with our observation, Sarvan et al. [31] reported $80 \%$ increase in GR concentration in broccoli after 2 min steaming. Ghawi et al. [7] observed 15, 11, and $5 \%$ increase in GR content in broccoli after 4, 8, and $12 \mathrm{~min}$ heat treatment at $80{ }^{\circ} \mathrm{C}$. Pérez et al. [17] investigated the optimization of blanching step to maximize sulforaphane synthesis in broccoli at temperatures ranging from $46-76^{\circ} \mathrm{C}$ for durations of $3-17 \mathrm{~min}$. They found a trend of increasing GR content as temperature increased, with the maximum content observed after 15 min heating at $70{ }^{\circ} \mathrm{C}$ which was $93 \%$ higher compared to fresh broccoli.

Our results showed that a combination of ultrasound with heat treatment (at 50 and $60{ }^{\circ} \mathrm{C}$ for 5 and $7 \mathrm{~min}$ ) improved the release of GR from broccoli matrix over and above the effect of heat treatment alone. This could be due to mechanical disruption of the plant cell wall and plant matrix, which enhances the release of intracellular content (plant constituents) by extraction [23]. The micro-streaming, micro-jets, and hydrodynamic shock waves generated during acoustic cavitation that creates an extreme shear forces, are believed to be responsible for mechanical rupture of plant tissue during ultrasonication [38]. The mass transfer increases due to acoustic cavitation can also facilitate diffusion rates, subsequently increasing GR extractability. Aguilar-Camacho, Welti-Chanes, and JacoboVelázquez [39] observed 795\% increase in GR extractability in broccoli florets by ultrasound treatment (400 W, 24 kHz, $100 \mu \mathrm{m}$ amplitude, $20 \mathrm{~min}$ ). Similarity, Pongmalai et al. [19] found $87 \%$ increase in GR content of steamed white cabbage by using combined ultrasoundassisted extraction ( $37 \mathrm{kHz}, 0.03 \mathrm{~W} / \mathrm{g}, 40 \mathrm{~min}$ ) and microwave-assisted extraction after 2 min steaming, compared with those in fresh cabbages without steaming indicating the potential of ultrasound for enhancing the extraction of GR as observed in this study.

\section{Conclusions}

This study showed that thermosonication treatment of broccoli florets at 50 to $60{ }^{\circ} \mathrm{C}$ enhances the yield of sulforaphane in broccoli puree compared to control. The highest sulforaphane yield was observed after $7 \mathrm{~min}$ thermosonication treatment of broccoli floret at $60{ }^{\circ} \mathrm{C}$, which resulted in 2.9 times more yield of sulforaphane compared to untreated broccoli. Thermal processing at the same condition $\left(60^{\circ} \mathrm{C} / 7 \mathrm{~min}\right)$ resulted in 2.5 more sulforaphane yield compared to the untreated control. The underlying mechanism appears to be not only the inactivation of ESP but also heat and ultrasound induced release and enhanced accessibility of glucoraphanin for myrosinase catalyzed conversion into sulforaphane. The results indicate that thermosonication treatment may improve sulforaphane yield over and above the effect of heat under the same condition, although further experiments at various ultrasonication conditions are required to confirm that. The study showed that thermosonication at relatively low power input $(0.6 \mathrm{~W} / \mathrm{g})$ enhances sulforaphane yield in broccoli indicating that the process can be used for cost effective conversion of broccoli biomass including low value second grade produce into high value ingredients enriched with sulforaphane for applications in food, nutraceutical, and pharmaceutical products. Further improvement in sulforaphane yield is possible via optimization of the ultrasonic processing condition.

Supplementary Materials: The raw sulforaphane, glucoraphanin and myrosinase activity data are available online at https:/ / www.mdpi.com/2218-273X/11/2/321/s1, Table S1. Effects of thermal and thermosonication processing on myrosinase activity, glucoraphanin content, and sul-foraphane yield in broccoli puree.

Author Contributions: Conceptualization, N.S.T., S.S. and M.A.A.; methodology, S.S.,H.J., N.S.T.; formal analysis, S.S.; investigation, S.S.; resources, N.S.T.; writing-original draft preparation, S.S., 
N.S.T.; writing—review and editing, S.S., N.S.T., H.J., M.A.A.; supervision, N.S.T. All authors have read and agreed to the published version of the manuscript.

Funding: The first author of this work, Sajad Shokri, was supported by the Ministry of Science, Research, and Technology of Iran.

Institutional Review Board Statement: Not applicable.

Informed Consent Statement: Not applicable.

Data Availability Statement: Data is available on request.

Conflicts of Interest: The authors declare no conflict of interest.

\section{References}

1. Rogers, G.; Ekman, J.; Titley, M. Identifying New Products, Uses and Markets for Australian Vegetables: A Desktop Study; Horticulture Australia Ltd.: Sydney, Australia, 2013; pp. 30-32. Available online: https://ausveg.com.au/app/data/technical-insights/docs/ 130052_VG12046.pdf (accessed on 20 February 2021).

2. Shi, M.; Hlaing, M.M.; Ying, D.; Ye, J.; Sanguansri, L.; Augustin, M.A. New food ingredients from broccoli by-products: Physical, chemical and technological properties. Int. J. Food Sci. Technol. 2019, 54, 1423-1432. [CrossRef]

3. Alvarez-Jubete, L.; Valverde, J.; Kehoe, K.; Reilly, K.; Rai, D.K.; Barry-Ryan, C. Development of a Novel Functional Soup Rich in Bioactive Sulforaphane Using Broccoli (Brassica oleracea L. ssp. italica) Florets and Byproducts. Food Bioprocess. Technol. 2013, 7, 1310-1321. [CrossRef]

4. Tahata, S.; Singh, S.V.; Lin, Y.; Hahm, E.-R.; Beumer, J.H.; Christner, S.M.; Rao, U.N.; Sander, C.; Tarhini, A.A.; Tawbi, H.; et al. Evaluation of Biodistribution of Sulforaphane after Administration of Oral Broccoli Sprout Extract in Melanoma Patients with Multiple Atypical Nevi. Cancer Prev. Res. 2018, 11, 429-438. [CrossRef]

5. Armah, C.N.; Derdemezis, C.; Traka, M.H.; Dainty, J.R.; Doleman, J.F.; Saha, S.; Leung, W.; Potter, J.F.; Lovegrove, J.A.; Mithen, R.F. Diet rich in high glucoraphanin broccoli reduces plasma LDL cholesterol: Evidence from randomised controlled trials. Mol. Nutr. Food Res. 2015, 59, 918-926. [CrossRef]

6. Sivapalan, T.; Melchini, A.; Saha, S.; Needs, P.W.; Traka, M.H.; Tapp, H.; Dainty, J.R.; Mithen, R.F. Bioavailability of Glucoraphanin and Sulforaphane from High-Glucoraphanin Broccoli. Mol. Nutr. Food Res. 2017, 62, e1700911. [CrossRef]

7. Ghawi, S.K.; Methven, L.; Niranjan, K. The potential to intensify sulforaphane formation in cooked broccoli (Brassica oleracea var. italica) using mustard seeds (Sinapis alba). Food Chem. 2013, 138, 1734-1741. [CrossRef]

8. Mokhtari, R.B.; Baluch, N.; Homayouni, T.S.; Morgatskaya, E.; Kumar, S.; Kazemi, P.; Yeger, H. The role of Sulforaphane in cancer chemoprevention and health benefits: A mini-review. J. Cell Commun. Signal. 2017, 12, 91-101. [CrossRef] [PubMed]

9. Axelsson, A.S.; Tubbs, E.; Mecham, B.; Chacko, S.; Nenonen, H.A.; Tang, Y.; Fahey, J.W.; Derry, J.M.J.; Wollheim, C.B.; Wierup, N.; et al. Sulforaphane reduces hepatic glucose production and improves glucose control in patients with type 2 diabetes. Sci. Transl. Med. 2017, 9, eaah4477. [CrossRef] [PubMed]

10. Martins, T.; Colaço, B.; Venâncio, C.; Pires, M.J.; Oliveira, P.A.; Rosa, E.; Antunes, L.M. Potential effects of sulforaphane to fight obesity. J. Sci. Food Agric. 2018, 98, 2837-2844. [CrossRef]

11. Román, J.; Castillo, A.; Cottet, L.; Mahn, A. Kinetic and structural study of broccoli myrosinase and its interaction with different glucosinolates. Food Chem. 2018, 254, 87-94. [CrossRef] [PubMed]

12. Kissen, R.; Rossiter, J.T.; Bones, A.M. The 'mustard oil bomb': Not so easy to assemble?! Localization, expression and distribution of the components of the myrosinase enzyme system. Phytochem. Rev. 2008, 8, 69-86. [CrossRef]

13. Bones, A.M.; Rossiter, J.T. The myrosinase-glucosinolate system, its organisation and biochemistry. Physiol. Plant. 1996, 97, 194-208. [CrossRef]

14. Bello, C.; Maldini, M.; Baima, S.; Scaccini, C.; Natella, F. Glucoraphanin and sulforaphane evolution during juice preparation from broccoli sprouts. Food Chem. 2018, 268, 249-256. [CrossRef] [PubMed]

15. Matusheski, N.V.; Juvik, J.A.; Jeffery, E.H. Heating decreases epithiospecifier protein activity and increases sulforaphane formation in broccoli. Phytochem. 2004, 65, 1273-1281. [CrossRef]

16. Matusheski, N.V.; Swarup, R.; Juvik, J.A.; Mithen, R.; Bennett, A.M.; Jeffery, E.H. Epithiospecifier Protein from Broccoli (Brassica oleracea L. ssp. italica) Inhibits Formation of the Anticancer Agent Sulforaphane. J. Agric. Food Chem. 2006, 54, $2069-2076$. [CrossRef] [PubMed]

17. Pérez, C.; Barrientos, H.; Román, J.; Mahn, A. Optimization of a blanching step to maximize sulforaphane synthesis in broccoli florets. Food Chem. 2014, 145, 264-271. [CrossRef]

18. Pongmalai, P.; Fu, N.; Soponronnarit, S.; Chiewchan, N.; Devahastin, S.; Chen, X.D. Microwave pretreatment enhances the formation of cabbage sulforaphane and its bioaccessibility as shown by a novel dynamic soft rat stomach model. J. Funct. Foods 2018, 43, 186-195. [CrossRef]

19. Pongmalai, P.; Devahastin, S.; Chiewchan, N.; Soponronnarit, S. Enhancing the recovery of cabbage glucoraphanin through the monitoring of sulforaphane content and myrosinase activity during extraction by different methods. Sep. Purif. Technol. 2017, 174, 338-344. [CrossRef] 
20. Wang, J.; Barba, F.J.; Sørensen, J.C.; Frandsen, H.B.; Sørensen, S.; Olsen, K.; Orlien, V. High pressure effects on myrosinase activity and glucosinolate preservation in seedlings of Brussels sprouts. Food Chem. 2018, 245, 1212-1217. [CrossRef] [PubMed]

21. Sarvan, I.; Verkerk, R.; Van Boekel, M.; Dekker, M. Comparison of the degradation and leaching kinetics of glucosinolates during processing of four Brassicaceae (broccoli, red cabbage, white cabbage, Brussels sprouts). Innov. Food Sci. Emerg. Technol. 2014, 25, 58-66. [CrossRef]

22. Van Eylen, D.; Oey, I.; Hendrickx, M.; Van Loey, A. Effects of pressure/temperature treatments on stability and activity of endogenous broccoli (Brassica oleracea L. cv. Italica) myrosinase and on cell permeability. J. Food Eng. 2008, 89, 178-186. [CrossRef]

23. Anaya-Esparza, L.M.; Velázquez-Estrada, R.M.; Roig, A.X.; García-Galindo, H.S.; Sayago-Ayerdi, S.G.; Montalvo-González, E. Thermosonication: An alternative processing for fruit and vegetable juices. Trends Food Sci. Technol. 2017, 61, 26-37. [CrossRef]

24. Sinisterra, J. Application of ultrasound to biotechnology: An overview. Ultrasonics 1992, 30, 180-185. [CrossRef]

25. Terefe, N.S.; Buckow, R.; Versteeg, C. Quality-Related Enzymes in Plant-Based Products: Effects of Novel Food-Processing Technologies Part 3: Ultrasonic Processing. Crit. Rev. Food Sci. Nutr. 2014, 55, 147-158. [CrossRef] [PubMed]

26. Tao, Y.; Zhang, Z.; Sun, D.-W. Kinetic modeling of ultrasound-assisted extraction of phenolic compounds from grape marc: Influence of acoustic energy density and temperature. Ultrason. Sonochem. 2014, 21, 1461-1469. [CrossRef] [PubMed]

27. Cai, C.; Miao, H.; Qian, H.; Yao, L.; Wang, B.; Wang, Q. Effects of industrial pre-freezing processing and freezing handling on glucosinolates and antioxidant attributes in broccoli florets. Food Chem. 2016, 210, 451-456. [CrossRef]

28. Cai, Y.X.; Wang, J.H.; McAuley, C.; Augustin, M.A.; Terefe, N.S. Fermentation for enhancing the bioconversion of glucoraphanin into sulforaphane and improve the functional attributes of broccoli puree. J. Funct. Foods 2019, 61, 103461. [CrossRef]

29. Ludikhuyze, L.; Ooms, V.; Weemaes, C.; Hendrickx, M. Kinetic study of the irreversible thermal and pressure inactivation of myrosinase from broccoli (Brassica oleracea L. Cv. italica). J. Agric. Food Chem. 1999, 47, 1794-1800. [CrossRef]

30. Terefe, N.S.; Gamage, M.; Vilkhu, K.; Simons, L.; Mawson, R.; Versteeg, C. The kinetics of inactivation of pectin methylesterase and polygalacturonase in tomato juice by thermosonication. Food Chem. 2009, 117, 20-27. [CrossRef]

31. Sarvan, I.; Van Der Klauw, M.; Oliviero, T.; Dekker, M.; Verkerk, R. The effect of chewing on oral glucoraphanin hydrolysis in raw and steamed broccoli. J. Funct. Foods 2018, 45, 306-312. [CrossRef]

32. Cai, Y.X.; Augustin, M.A.; Jegasothy, H.; Wang, J.H.; Terefe, N.S. Mild heat combined with lactic acid fermentation: A novel approach for enhancing sulforaphane yield in broccoli puree. Food Funct. 2020, 11, 779-786. [CrossRef] [PubMed]

33. Latté, K.P.; Appel, K.-E.; Lampen, A. Health benefits and possible risks of broccoli-An overview. Food Chem. Toxicol. 2011, 49, 3287-3309. [CrossRef]

34. Jones, R.; Frisina, C.; Winkler, S.; Imsic, M.; Tomkins, R. Cooking method significantly effects glucosinolate content and sulforaphane production in broccoli florets. Food Chem. 2010, 123, 237-242. [CrossRef]

35. Sarvan, I.; Kramer, E.; Bouwmeester, H.; Dekker, M.; Verkerk, R. Sulforaphane formation and bioaccessibility are more affected by steaming time than meal composition during in vitro digestion of broccoli. Food Chem. 2017, 214, 580-586. [CrossRef] [PubMed]

36. Bones, A.M.; Rossiter, J.T. The enzymic and chemically induced decomposition of glucosinolates. Phytochemistry 2006, 67, 1053-1067. [CrossRef] [PubMed]

37. Živković, J.; Šavikin, K.; Janković, T.; Ćujić, N.; Menković, N. Optimization of ultrasound-assisted extraction of polyphenolic compounds from pomegranate peel using response surface methodology. Sep. Purif. Technol. 2018, 194, 40-47. [CrossRef]

38. Chemat, F.; Rombaut, N.; Sicaire, A.-G.; Meullemiestre, A.; Fabiano-Tixier, A.-S.; Abert-Vian, M. Ultrasound assisted extraction of food and natural products. Mechanisms, techniques, combinations, protocols and applications. A review. Ultrason. Sonochem. 2017, 34, 540-560. [CrossRef]

39. Aguilar-Camacho, M.; Welti-Chanes, J.; Jacobo-Velázquez, D.A. Combined effect of ultrasound treatment and exogenous phytohormones on the accumulation of bioactive compounds in broccoli florets. Ultrason. Sonochem. 2019, 50, 289-301. [CrossRef] [PubMed] 